\title{
Utilization of Bar Soap (Sabbath) Becomes Liquid Hand Soap to Prevent the Spread of Covid-19 (Community Service in Singocandi Village, City District, Kudus Regency)
}

\author{
Munawar Kholil \\ Universitas Sebelas Maret, \\ munawarkholil@staff.uns.ac.id
}

\section{Article History}

accepted 31/08/2020

\begin{abstract}
The problems of the people of Singocandi Village RT 001 RW 002 related to the habit of using bar soap as hand washing soap are increasing. Bar soap is recommended to only be used by one person. The use of bar soap interchangeably is not recommended because it is not hygienic and is thought to be able to transmit disease. Moreover, it is used as hand soap by the whole family. The purpose of the activity of using bar soap into liquid hand washing soap is a form of the Covid-19 Community Service Program which is carried out in Singocandi Village to maintain cleanliness and body health and increase the creativity of local residents. Processing of bar soap, if developed, is expected to increase the habit of a clean and healthy lifestyle and increase income in Singocandi Village. The method of implementation carried out in this activity is: (1) delivery of material on how to make liquid hand soap from bar soap. (2) practice with the children of RT 001 / RW 002. The result is increased knowledge, innovation and creativity, the creation of liquid soap products, and habits of a clean and healthy lifestyle
\end{abstract}

Keywords: Soap, Bars, Liquid.

Abstrak

Permasalahan masyarakat Desa Singocandi RT 001 RW 002 terkait kebiasaan penggunaan sabun batang sebagai sabun cuci tangan semakin meningkat. Sabun batang dianjurkan hanya bisa digunakan oleh satu orang. Penggunaan sabun batang secara bergantian tidak disarankan karena tidak higienis dan dianggap bisa menularkan penyakit. Apalagi digunakan sebagai sabun cuci tangan oleh seluruh anggota keluarga. Tujuan kegiatan pemanfaatan sabun batang menjadi sabun cuci tangan cair adalah bentuk kegiatan KKN COVID-19 yang dilaksanakan di Desa Singocandi guna menjaga kebersihan dan kesehatan tubuh dan meningkatkan kreatifitas warga setempat. Pengolahan sabun batang jika dikembangkan diharapkan dapat meningkatkan kebiasaan pola hidup bersih dan sehat dan meningkatkan pendapatan di Desa Singocandi Metode pelaksanaan yang dilakukan dalam kegiatan ini adalah: (1) penyampaian materi tentang cara pembuatan sabun cuci tangan cair dari sabun batang. (2) praktik bersama anakanak RT 001/RW 002. Hasilnya adalah meningkatnya pengetahuan, inovasi, dan kreatifitas, terciptanya produk sabun cair, dan kebiasaan pola hidup bersih dan sehat.

Kata kunci: Sabun, Batang, Cair.

Social, Humanities, and Education Studies (SHEs): Conference Series https://jurnal.uns.ac.id/shes 


\section{PENDAHULUAN}

Desa Singocandi merupakan salah satu desa yang terletak di Kecamatan Kota, Kabupaten Kudus dengan jumlah penduduk kurang lebih mecapai 14.875 jiwa. Pada RT 001/RW 002 jumlah penduduknya cukup banyak sehingga banyak pula pembelian akan kebutuhan sehari-hari seperti sabun batang.

Perilaku hidup bersih dan sehat (PHBS) merupakan langkah yang harus dilakukan untuk mencapai derajat kesehatan yang optimal bagi setiap orang. Kondisi sehat tidak serta merta dapat terjadi secara instan, tetapi harus senantiasa diupayakan dari yang tidak sehat menjadi hidup yang sehat serta menciptakan lingkungan yang sehat. Upaya ini harus dimulai dari menanamkan pola pikir sehat kepada masyarakat yang harus dimulai dan diusahakan oleh diri sendiri (Andriansyah, 2013). Mengingat kondisi yang terjadi saat ini sedang marak dilanda pandemic virus Covid-19. Salah satu bentuk perilaku hidup bersih dan sehat (PHBS) adalah gerakan mencuci tangan menggunakan sabun dan air mengalir. Sabun yang baik adalah sabun yang tepat digunakan untuk mencuci tangan yakni sabun cair. Penggunaan sabun cair diharapkan dapat menciptakan peningkatan pola hidup bersih dan sehat agar terhindar dari jangkauan virus Covid-19.

Sabun mempunyai kemampuan untuk mengemulsi berupa kotoran berminyak yang mana dapat dibuang dengan cara pembilasan (Fauzi, 2019). Secara umum, sabun dapat dibagi menjadi dua jenis berdasarkan wujudnya, yakni sabun cair dan sabun batang. Karena dari segi bentuk saja sudah berbeda, sabun cair maupun sabun batang jelas memiliki kelebihan dan kekurangan masing-masing. Sabun cair pada umumnya tersedia dalam wadah yang tertutup atau dikemas khusus untuk menghindari kontak langsung dengan pengguna. Dengan begitu, sabun jenis ini diyakini lebih higienis dibanding sabun batang. Selain lebih higienis, sabun cair dianggap lebih mudah untuk digunakan. Apabila ingin dimanfaatkan, sabun jenis ini tinggal dituangkan secara manual atau menggunakan pompa yang tersedia dalam wadah. Namun sayang, harga sabun cair di pasaran cenderung lebih tinggi apabila dibanding dengan sabun batang. Harga sabun cair bahkan bisa mencapai 5 kali lipat lebih mahal apabila dibandingkan dengan harga sabun batang. Hal itu memang bisa jadi lumrah mengingat kurang efektifnya dari penggunaan sabun batang.

Sedangkan sabun batang merupakan jenis sabun yang harus disimpan dengan baik setelah dibuka dari bungkusnya. Apabila wadah penyimpanannya terkena air, maka lama-kelamaan sabun batang akan cepat habis. Selain itu, sabun batang dianjurkan hanya bisa digunakan oleh satu orang. Penggunaan sabun batang secara bergantian tidak disarankan karena tidak higienis dan dianggap bisa menularkan penyakit dari orang satu ke orang lainnya

Di masa pandemi Covid-19, masyarakat khususnya anak- anak diharuskan untuk melakukan segala kegiatan dari dirumah seperti belajar dan bermain, sehingga menimbulkan rasa bosan dan jenuh. Pelaksanaan kegiatan pemanfaatan sabun batang diharapkan menjadikan anak-anak lebih produktif saat berada di rumah. Sabun cuci tangan cair sendiri banyak dicari masyarakat saat pandemi COVID-19, dikarenakan himbauan pemerintah untuk rajin mencuci tangan memakai sabun, pada tempat-tempat publik juga dianjurkan terdapat tempat cuci tangan, karena meningkatnya permintaan akan sabun cuci tangan menjadikan harganya menjadi naik.

Adapun pada kesempatan kali ini, kegiatan relawan mahasiswa - mahasiswi yang tergabung dalam KKN UNS tanggap wabah Covid-19 mengajak masyarakat Desa Singocandi RT 001 / RW 002 terutama anak-anak untuk mengikuti salah satu program kerja pembuatan sabun cuci tangan cair dari sabun batang. 


\section{METODE}

Pelaksanaan KKN UNS periode Februari - Juli 2020 ini memang berbeda dari sebelumnya. Mahasiswa yang melaksanakan KKN UNS Covid-19 ini ditempatkan pada daerah masing - masing dengan tujuan menekan angka Covid-19. Kelompok KKN UNS Covid-19 pada penelitan ini tergabung dalam satu wilayah administrasi yaitu Desa Singocandi yang terletak di Kecamatan Kota, Kabupaten Kudus. Penekanan pada program kerja yang diusung tiap mahasiswa pelaksana KKN periode ini menjadi salah satu ciri pembeda apabila dibandingkan dengan KKN sebelumnya. Lokasi praktik pembuatan sabun cuci tangan cair dilakukan di salah satu rumah milik warga RT 001. Anak-anak yang menjadi peserta pelatihan pada kegiatan yang dilaksanakan ini, sebelumnya diberikan penjelasan tentang manfaat, alat dan bahan, serta langkahlangkah pembuatan dari awal hingga akhir. Praktik pembuatan sabun cuci tangan cair dilakukan secara langsung setelah penjelasan lengkap tersampaikan. Praktik dimulai dengan mempersiapkan sabun batang dan bahan- bahan lainnya. Pembuatan sabun cuci tangan cair sangat mudah sehingga anak-anak tidak kesulitan dalam proses pembuatan.

Metode yang diterapkan dalam pemberdayaan masyarakat pada kegiatan kuliah kerja nyata tanggap Covid-19 (KKN UNS Covid-19) ini adalah sebagai berikut: (1) penyampaian materi tentang cara pembuatan sabun cuci tangan cair dari sabun batang yang dilanjutkan dengan (2) praktik bersama anak-anak RT 001/ RW 002 Desa Singocandi, Kecamatan Kota, Kabupaten Kudus.

\section{HASIL DAN PEMBAHASAN}

\section{Materi Tentang Cara Pembuatan Sabun Cuci Tangan Cair Dari Sabun Batang}

Program kerja yang diusung pada KKN UNS Covid-19 yang dilaksanakan di RT 001/ RW 002, Desa Singocandi, Kecamatan Kota, Kabupaten Kudus adalah pembuatan sabun cuci tangan cair. Praktik pembuatan sabun cuci tangan cair yang dilakukan oleh anak-anak RT 001/ RW 002 dapat meningkatkan kreatifitas dan menambah pengetahuan untuk melakukan hal-hal yang produktif di waktu luang, serta dengan adanya pengolahan sabun batang membuat sabun batang menjadi bernilai ekonomis. Adapun proses pembuatan sabun cuci tangan cair dari sabun batang diuraikan sebagai berikut:

\section{Bahan dan Alat}

Pembuatan sabun cuci tangan cair membutuhkan bahan meliputi sabun batang, air panas, garam, Dettol Antiseptik, parutan, saringan, tempat plastik (ember), sendok, tempat sabun cuci tangan cair yang sudah jadi (botol pump atupun botol bekas aqua). Bahan - bahan yang diperlukan masih dapat ditemukan dan memiliki harga yang terjangkau sehingga harapannya program ini dapat di aplikasikan secara berkelanjutan kedepannya.

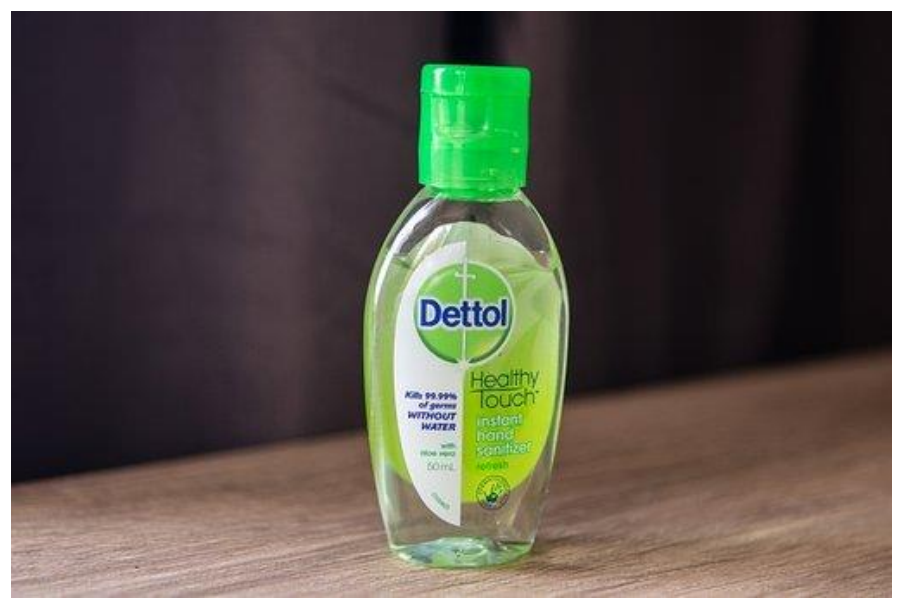




\section{Gambar 1. Dettol Antiseptik}

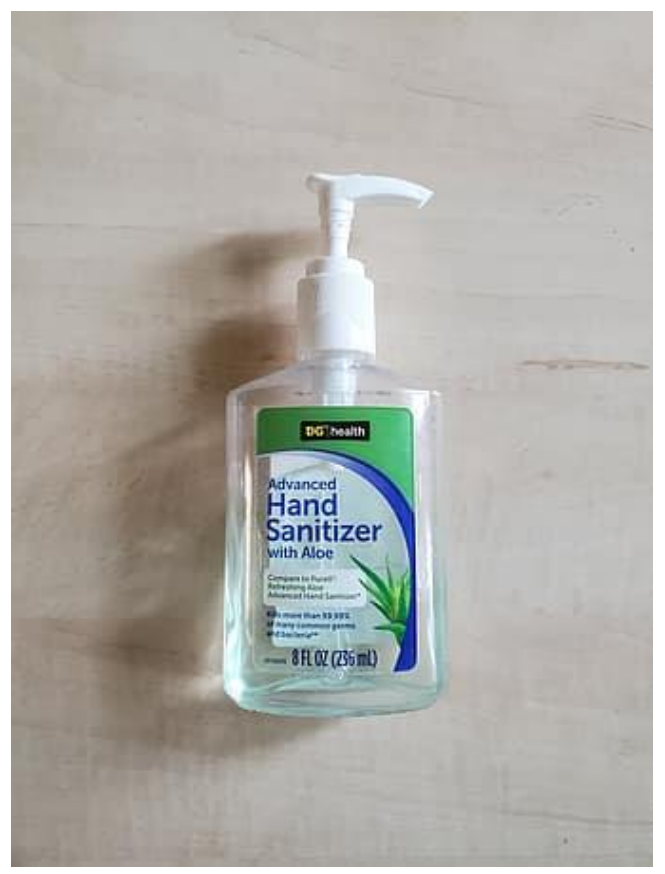

Gambar 2. Botol Pump

\section{Proses Pembuatan Sabun Cuci Tangan Cair dari Sabun Batang}

Pembuatan sabun ini dilakukan oleh anak - anak yang tingal di RT 001/RW 002, Desa Singocandi, Kecamatan Kota, Kabupaten Kudus. Anak - anak yang diundang kemudian dibagi menjadi beberapa kelompok dengan jumlah minimal tiap kelompok dengan tujuan menghindari kerumunan. Pembagian sabun batang sebagai bahan utama (main ingredient) dilakukan kepada ketua tiap kelompok. Kemudian anak - anak dihimbau untuk memarut sabut batang yang sudah dibagikan dan tempatkan di wadah yang sudah disediakan. Parutan sabun batang tadi kemudian dituangkan air panas agar meleleh. Adonan sabun batang yang sudah setengah jadi kemudian ditambahkan garam sebanyak 1 sdt (sendok teh) lalu diaduk secara perlahan. Apabila dirasa sudah cukup tercampur, adonan sabun batang tadi dipisahkan bagian yang masih kasar agar tidak menimbulkan scrub saat disemprotkan. Cairan sabun batang tadi kemudian tambahkan 1 sdt Dettol Antiseptic agar harum dan terdapat antiseptic di dalam cairan kemudian diaduk secara perlahan. Langkah terakhir adalah menuangkan cairan sabun ke dalam wadah yaitu botol pump yang sudah disiapkan. Sabun cuci tangan cair siap digunakan.

Pemanfaatan sabun batang menjadi sabun cuci tangan cair berdampak positif untuk kebersihan dan kesehatan masyarakat, karena masyarakat menjadi rajin mencuci tangan dengan sabun yang tepat. Penggunaan sabun cair sangat meminimalkan potensi kontak fisik antar pengguna. Mengingat peredaran virus yang sedang marak terjadi di Indonesia yaitu virus Covid-19 yang dapat beredar melalui 
kontak fisik. Permintaan yang meningkat akan sabun cuci tangan cair saat pandemi COVID-19 menjadikan peluang sumber pendapatan warga.

Anak - anak RT 001/ RW 002, Desa Singocandi, Kecamatan Kota, Kabupaten Kudus menunjukkan antusiasme tinggi selama proses praktik pembuatan sabun cuci tangan cair. Antusiasme tersebut ditunjukkan dengan respon yang sangat baik dalam menerima penjelasan mengenai prosedur pembuatan, serta kemauan untuk terlibat dalam setiap tahap proses pembuatan sabun cuci tangan cair. Antusiasme tersebut diharapkan dapat meningkatkan inovasi dan kreatifitas anak-anak serta mengembangkan bakat anak sejak dini.

Produk sabun cuci tangan cair yang telah selesai dibuat oleh anak - anak RT 001/ RW 002, Desa Singocandi, Kecamatan Kota, Kabupaten Kudus kemudian dipakai mereka sendiri bersama keluarganya dan ditempatkan di musholla atau masjid, beberapa warung sekitar desa, dengan memberi keterangan cara penggunaan dan pembuatannya, sehingga warga juga dapat membuatnya sendiri, dengan pengembangan produk dari sabun batang yang bernilai ekonomis, dapat meningkatkan pendapatan masyarakat RT 001 / RW 002, Desa Singocandi, Kecamatan Kota, Kabupaten Kudus. Penempatan sabun cuci tangan cair dipilih pada lokasi - lokasi yang dirasa membentuk kerumunan aktivitas.

\section{SIMPULAN}

Pemanfaatan dari sabun cuci tangan batang menjadi sabun cuci tangan cair ini dapat meningkatkan pengetahuan, inovasi dan kreatifitas anak-anak RT 001 / RW 002, Desa Singocandi, Kecamatan Kota, Kabupaten Kudus dalam mengolah sabun batang menjadi sabun cuci tangan cair. Selain itu dapat meningkatkan pendapatan masyarakat RT 001 / RW 002, Desa Singocandi, Kecamatan Kota, Kabupaten Kudus , serta meningkatkan gerakan cuci tangan menggunakan sabun cuci tangan cair supaya terhindar dari berbagai penyakit terutama pada saat masa pandemi Covid-19.

\section{DAFTAR PUSTAKA}

Andriansyah, Yuli, dan Desi Natalia Rahmantari. 2013. "Penyuluhan dan Praktik PHBS (Perilaku Hidup Bersih Sehat) dalam Mewujudkan Masyarakat Desa Peduli Sehat". Jurnal Inovasi dan Kewirausahaan. Vol. 2, No. 1. HIm. 45-50.

Fauzi, Indah Gusti, dkk. 2019. "Industri Sabun". Jurnal Universitas Negeri Padang. HIm. 1-29.

Sari, Rafika, dan Ade Ferdian. 2017. "Pengujian Aktivitas Antibakteri Sabun Cair dari Ekstrak Kulit Daun Lidah Buaya". Pharm Sci Res. Vol. 4, No. 3. HIm. 111-120 